\title{
A linguagem em sujeitos com a síndrome do X-Frágil: discursos e contradiscursos
}

DOI: http://dx.doi.org/10.21165/el.v49i3.2676

\section{Michelli Alessandra Silva Tortelly'}

\section{Resumo}

A linguagem ainda é alvo de avaliações descontextualizadas, amparadas em testespadrão, que pouco consideram da subjetividade e do trabalho criativo que sujeitos, com e sem patologias, exercem sobre ela. O discurso científico, veiculado em diferentes publicações (artigos, textos em sites de associações e entidades relacionadas à patologia), sobre a Síndrome do X-Frágil não se esquiva desse olhar equivocado e reducionista sobre a linguagem. Para me contrapor a esse discurso, apresento dados do processo de aquisição e uso da fala, leitura e escrita de um sujeito portador da síndrome, destacando seu trabalho linguístico-cognitivo e as marcas de subjetividade na linguagem. A discussão dos dados procura identificar em suas dificuldades linguísticas aquilo que pode ser patológico, o que faz parte do processo normal de aquisição e uso da fala/ leitura/escrita e o que pode estar relacionado a outros fatores, que podem ser de ordem social ou relativos à história de vida do sujeito.

Palavras-chave: fala/leitura/escrita; neurolinguística discursiva; contradispositivos.

1 Universidade Estadual de Campinas (UNICAMP), Campinas, São Paulo, Brasil; m.alessandra.silva@gmail.com; https://orcid.org/0000-0002-2007-845X 


\title{
Language in subjects with Fragile $X$ Syndrome: discourses and counter-speeches
}

\begin{abstract}
Language is still the target of decontextualized evaluations, supported by standard tests, which consider little of the subjectivity and creative work that subjects, with and without pathologies, exert on it. The scientific discourse, published in different publications (articles, texts on sites of associations and entities related to pathology), about the Fragile $X$ Syndrome does not shy away from this view mistaken and reductionist about language. To counteract this discourse, I present some data about the process of speech, reading and writing acquisition/use of one subject with the syndrome highlighting his linguisticcognitive work and the marks of his subjectivity in language. I attempt to identify these subject's language difficulties in order to point out what may be pathological, what is part of a normal speech, reading and writing acquisition/use and what may be related to other factors, which may be of a social order or related to the subject's life history.
\end{abstract}

Keywords: speech/reading/writing; discursive neurolinguistcs; counter-apparatus.

\section{Introdução}

A Síndrome do X-Frágil (SXF) é uma doença hereditária ligada ao cromossomo $\mathrm{X}$, considerada uma das causas mais comuns de comprometimento intelectual de etiologia genética. Segundo a literatura da área, a síndrome está relacionada à presença de uma região de fragilidade, mais sujeita à ocorrência de quebras ou falhas, localizada na porção distal do braço longo do cromossomo $X$ - sítio frágil $[f r a(X)]$. O gene que se vincula ao fenótipo anômalo é designado FMR-1, cujo produto é uma proteína (FMRP) necessária para o desenvolvimento e função normais do cérebro, executando um papel essencial tanto na função sináptica como no crescimento dos dendritos (DARNEL et al., 2001). Por essa razão, na SXF, a comunicação entre os neurônios fica comprometida, uma vez que a produção dessa proteína é alterada.

Nos últimos anos, estudos vêm sendo feitos com a preocupação, principalmente, de descobrir as características clínicas dos portadores da SXF, a partir de pesquisas citogenéticas, encefalográficas e de imagem (GUERREIRO et al., 1998; BOY et al., 2001). Alguns desses estudos relatam como características predominantes nesses sujeitos: face alongada, orelhas grandes e em abano, mandíbula proeminente, hipotonia muscular, comprometimento do tecido conjuntivo, hiperextensibilidade das articulações, palato alto, prolapso da válvula mitral, prega palpar única, estrabismo, calosidade nas mãos devido à mordedura, retardo mental e motor, hiperatividade, défıcit de atenção, difıculdade de contato físico com outra pessoa, contato visual escasso, ansiedade social, autismo, resistência a mudanças no ambiente, entre outras. Dentre as dificuldades relacionadas 
à linguagem apontam: fala perseverativa, fala fora do contexto, ecolalia, atrasos no aparecimento das primeiras palavras, dispraxias verbais, alterações na percepção e articulação dos sons, alterações no ritmo e velocidade da fala, dificuldades para manter diálogo e fixar-se em assuntos da conversação, dificuldade para reter informações ou assimilar noções abstratas (como as requeridas pela leitura /escrita: perceber, relacionare fixar sequências na estrutura de sons e letras com significado), dificuldade em generalizar e aplicar informações em situações novas (FUNDAÇÃO BRASILEIRA DA SÍNDROME DO X FRÁGIL, 2010).

\section{Discurso médico}

Na caracterização da SXF, o que se percebe é que todas as particularidades, enumeradas anteriormente sejam elas comportamentais, físicas, e associadas a outras patologias (Déficit de Atenção, Hiperatividade, Autismo), bem como possíveis dificuldades de linguagem, são descritas como sintomas da síndrome compondo uma espécie de conhecimento sobre a doença que assegura que um determinado campo de saber neste caso, a medicina - tenha o poder de identificá-la e diferenciá-la de outras; bem como definir o que é ou não patológico a partir de características diversas que, juntas, constituem o que Foucault chama de estado. A noção de estado traz vantagens a esse campo de saber, pois, por um lado, como vimos na descrição da síndrome, põe em relação qualquer elemento físico ou comportamento desviante, por mais díspares e distantes que sejam, como se existisse uma espécie de fundo unitário que os explicasse; e, por outro lado, constrói um modelo fisiológico, isto é, um conjunto estrutural característico de um indivíduo, que ou teve seu desenvolvimento interrompido, ou regrediu de um estado de desenvolvimento ulterior a um anterior (FOUCAULT, 2001).

No caso da SXF, por ser uma doença hereditária de etiologia genética, o estado congênito possibilita ainda que a hereditariedade seja tomada como a origem do estado anormal, o que traz a esse campo de saber mais outras duas vantagens: (i) confere aos ancestrais a responsabilidade, por serem eles os transmissores do gene anômalo - referindo-se, assim, aos mecanismos anteriores de reprodução e colocando em suspenso a questão da sucessão familiar; (ii) e a possibilidade de que tudo pode ser causa da patologia.

Para exemplificar, cito algumas afırmações de pesquisas sobre a SXF encontradas em artigos científicos, textos de sites de associações e entidades relacionadas à patologia, bem como em textos publicados em sites de eventos e conferências.

Em um estudo (YONAMINE; SILVA, 2002) com 10 meninos portadores da SXF, com idades entre 6 e 13 anos, foi caracterizado o nível de comunicação desses indivíduos a partir de escalas de desenvolvimento normal. Para a realização do estudo, as autoras dividiram os sujeitos em dois grupos, segundo a forma de comunicação: pré-linguística e linguística. Como resultado, apresentam as seguintes conclusões: 
Diante dos dados obtidos, confirma-se que pacientes com SXF apresentam notável atraso nos padrões de comunicação linguística, visto que se constatou que, entre a faixa etária de 6 e 13 anos, os indivíduos avaliados apresentaram comunicação pré-linguística ou linguística, até o nível de 3 anos. É importante o diagnóstico precoce que permita uma intervenção terapêutica o mais breve possível, além de se poder realizar a orientação familiar quanto aos aspectos genéticos o mais precocemente possível. (YONAMINE; SILVA, 2002, p. 985).

As autoras apresentam ainda estudos que corroboram seus achados e citam que, em relação à evolução do QI, homens com a SXF demonstram declínio nos resultados, sendo o período mais marcante o início da puberdade (11 a 15 anos), sugerindo a existência de processo degenerativo contínuo (HODAPP et al., 1990). Outros estudos (SPINELLI et al., 1995; SUDHALTER; MARANION; BROOKS, 1992) apontam que os indivíduos com SXF apresentam não apenas déficits relacionados à sintaxe, mas igualmente à semântica, como dificuldade de evocação de palavras e pouca habilidade em escolher a palavra correta do léxico mental, ao tentar produzir um pensamento com significado e bem estruturado.

Essa visão revela uma concepção de desenvolvimento² (estanque, com estágios delimitados) e de linguagem (a-histórica, como sinônimo de comunicação), pautada em um padrão estabelecido de normalidade, marcado linguisticamente por palavras e expressões como: evolução do QI, níveis de comunicação, déficits relacionados à sintaxee à semântica, comunicação pré-linguística e linguística. No mesmo sentido, as avaliações de linguagem utilizadas para classificar o sujeito são em sua maioria padronizadas, pautadas em atividades descontextualizadas, e comparam os resultados do sujeito portador de uma patologia que afeta o funcionamento cerebral (como é o caso da criança ou do jovem com a SXF) com os de um sujeito sem patologia - concluindo dessa comparação que o anormal é o que se desvia do padrão e o normal o que é estabelecido como padrão, em geral baseado na gramática normativa e distante dos diversos usos da linguagem que o sujeito realiza. E são muitos os estudos que adotam essas ferramentas para avaliar, diagnosticar, classificar, rotular.

Em revisão de literatura, Ferreira e Lamônica (2005) constataram que a maioria dos estudos acerca da SXF usa testes psicométricos para medir o nível de inteligência dos sujeitos. As autoras verificaram que 12 dentre 15 estudos revistos usam protocolos padronizados para avaliar fala e linguagem. Nessa revisão, o WISC-R (Wechsler Intelligence

2 Assumo, neste artigo, a concepção de desenvolvimento segundo Vygotsky (1998), entendido como um processo no qual se integram cultura e história. Tornam-se relevantes as situações concretas de vida, a linguagem e as relações de ensino. Para Vygotsky, o processo de desenvolvimento não é linear e destaca que é pela mediação do outro e da linguagem que a criança gradativamente penetra em um universo de significações sociais e culturais, constituindo-se enquanto ser social e humano. 
Scale for Children-Revised) é apontado como um dos testes mais utilizados. Abaixo, apresento trechos do subteste de vocabulário do WISC-R, que compõe parte do cálculo do desempenho e pontuação total da escala em relação à Compreensão Verbal ${ }^{3}$.

No subteste de vocabulário, a instrução é para que o teste seja interrompido após cinco fracassos consecutivos. O examinador deve dizer à criança: "Vou dizer algumas palavras. Escute-as atentamente e me diga o que significa cada palavra". Para cada palavra, o examinador deve perguntar: "O que significa...?" Segue-se uma lista de 32 palavras dentre as quais: faca, relógio, ladrão, burro, valente, chapéu, juntar, emigrar, alfabeto, rivalidade. São apresentados exemplos de respostas para cada palavra com as pontuações a serem atribuídas. Por exemplo, para a palavra "relógio" atribuem-se dois pontos quando a criança responde "serve para ver a hora", "é um instrumento para medir o tempo"; atribuise um ponto se a criança responde "tem ponteiros", "faz tic-tac", "tem a ver com o tempo", "é uma coisa redonda que me diz quando eu tenho que ir para a escola e quando eu tenho que voltar"; e não é considerado correto (ou seja, a pontuação é zero) quando a criança responde "fica pendurado na minha cozinha", "é uma coisa que dá voltas", "eu uso no pulso".

Testes, como este, deixam de considerar a relação do sujeito com a linguagem, a realidade em que vive e as possibilidades de trabalho criativo com a linguagem (FRANCHI, 1992). São testes que têm a pretensão de determinar o máximo de inteligência ou nível linguístico que uma criança pode atingir, a partir de uma visão restrita de língua e das variedades existentes, distanciando-se do funcionamento discursivo. Testes que determinarão as condutas escolares e terapêuticas a serem seguidas pelos profissionais.

\section{Conduta adotada na clínica e na escola}

Apresento, a seguir, um exemplo de conduta terapêutica, fonoaudiológica, pautada no discurso da área médica, em que a linguagem (sem sentido) torna-se uma atividade mecânica de repetições de sons relacionados a uma forma de produção fonoarticulatória. Trata-se de um dado do caderno de RG (com 18 anos à época) em que eram realizadas as atividades passadas pela Fonoaudióloga que o acompanhava há cinco anos.

3 Para o cálculo total desse fator - Compreensão Verbal - são ainda considerados os desempenhos e pontuações dos subtestes Informação, Analogias e Compreensão. 
RG foi encaminhado ao CCazinho ${ }^{4}$ em março de 2011. É o único caso de X-Frágil conhecido pela família e foi diagnosticado em 2000 como portador da síndrome. Até o período de seu acompanhamento, frequentava uma escola para crianças e jovens com deficiências múltiplas e trabalhava meio período no estoque de uma loja de artigos esportivos e calçados. Em um primeiro encontro, RG pouco falou e se mostrou bastante tímido.

A mãe relatou que havia estado com o neurologista no dia anterior, que afirmou que RG jamais aprenderia a ler e escrever e na ocasião ela levou uma pasta com todos os diagnósticos e exames do jovem. Em um dos laudos médicos, realizado por um psiquiatra infantil, o profissional destaca como uma das características de RG a "forte inflexibilidade cognitiva" e, por isso, a "necessidade da manutenção da rotina" em sua vida. E como é possível mudar se as tarefas são sempre as mesmas? Esse é mais um exemplo do discurso que caracteriza, em geral, a área médica, o que contribui fortemente para manter o sujeito no lugar da não aprendizagem.

Figura 1. Escrita e fala na clínica

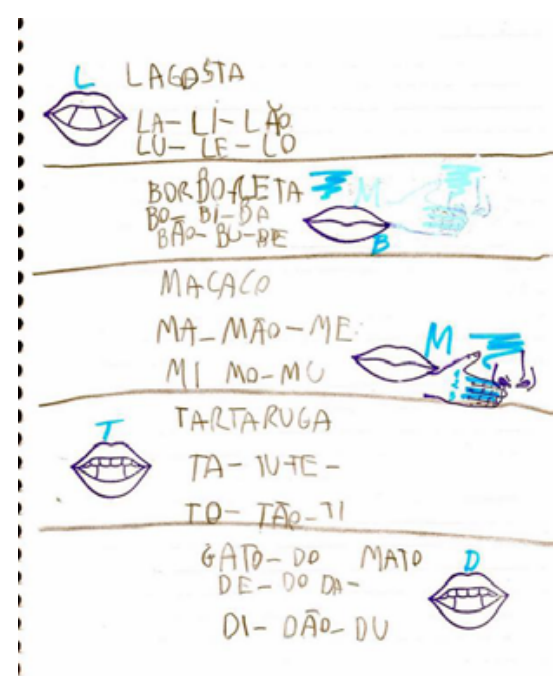

Fonte: Caderno das Sessões Fonoaudiológicas de RG

\footnotetext{
40 Centro de Convivência de Linguagens (CCazinho) teve início em 2004, no Instituto de Estudos da Linguagem da UNICAMP, por iniciativa da Profa. Coudry. É um lugar de pesquisa, formação e extensão onde se desenvolve um trabalho com a linguagem, por meio de práticas de leitura e escrita com crianças e jovens que receberam diagnósticos neurológicos (Dificuldades de Aprendizagem, Dislexia, Alteração do Processamento Auditivo, Transtorno do Déficit de Atenção com ou sem Hiperatividade, Deficiência Mental). A atribuição de tais diagnósticos tem sido uma justificativa eficaz para o fracasso e a exclusão escolar, além da patologização de processos normais - contra o que nos posicionamos. Desenvolvemos um conjunto de contradispositivos (AGAMBEN, 2009) e contradiscursos (COUDRY, 2009, 2010) que produzem efeitos positivos no processo de entrada na leitura/escrita, fortalecendo as crianças e suas famílias no enfrentamento da questão, o que tem possibilitado reverter tal condição.
} 
O dado anterior mostra como é equivocada a visão de linguagem a que RG está exposto na clínica: a forma da boca para ser produzido um som que corresponde a determinada letra é sinalizada com um carimbo de uma boca. No entanto, há sons diferentes cujo ponto de articulação é o mesmo (como t/d) e, portanto, o desenho da boca no carimbo não muda. Abaixo da palavra que tem a letra que está sendo representada pelo carimbo vem um conjunto do que parece ser a família silábica, porém, sem nenhuma sequência e ainda com uma palavra formada pela letra e a terminação -ão (lão, bão, mão, tão, dão). Qual é o sentido de escrever nesse tipo de tarefa?

Os dados do caderno escolar de RG demonstram que, na escola, as atividades parecem não ser lidas pelo professor e não há reescrita . Observe a lista de "palavras" abaixo e em seguida o texto que é visto pela professora que coloca "certo", mas, no entanto, não é reescrito. Qual é a função dessa escrita se não há reescrita e qual é o sentido de escrever listas de palavras sem nenhuma finalidade?

Figura 2. Escrita na escola 1

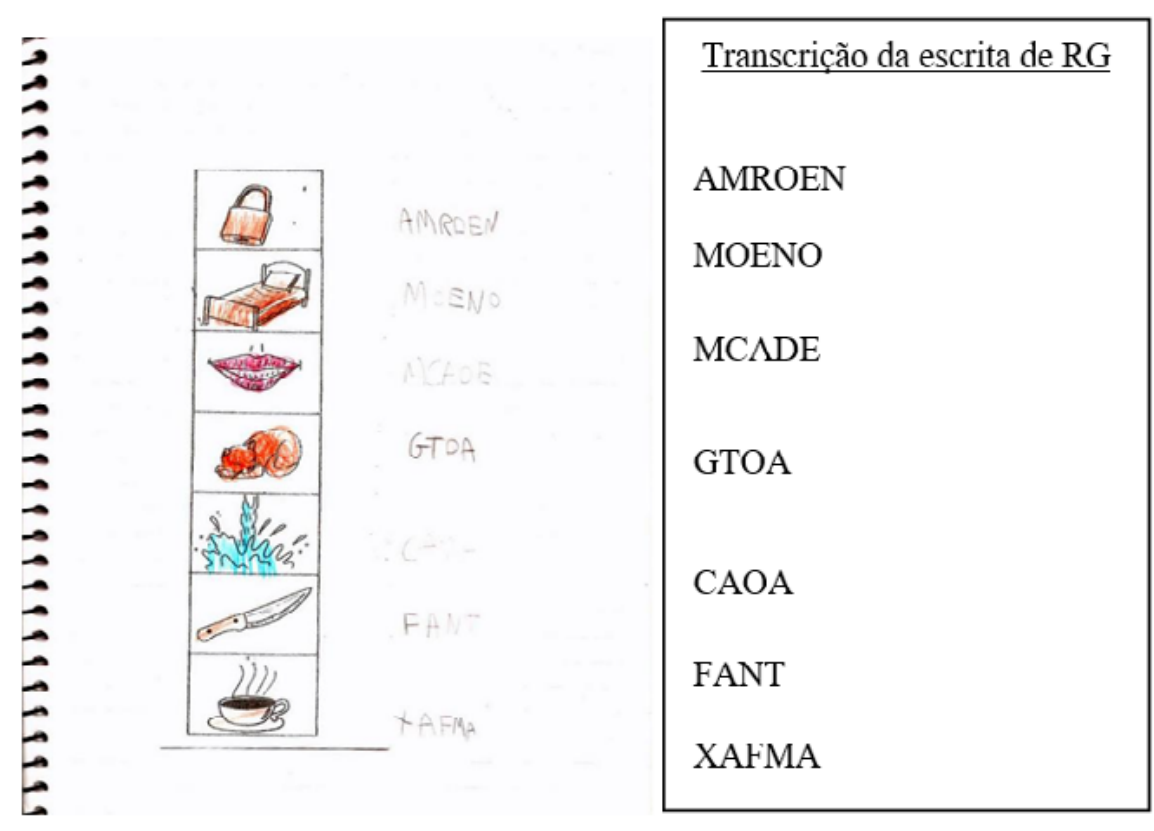

Fonte: Caderno Escolar de RG 
Figura 3. Escrita na escola 2

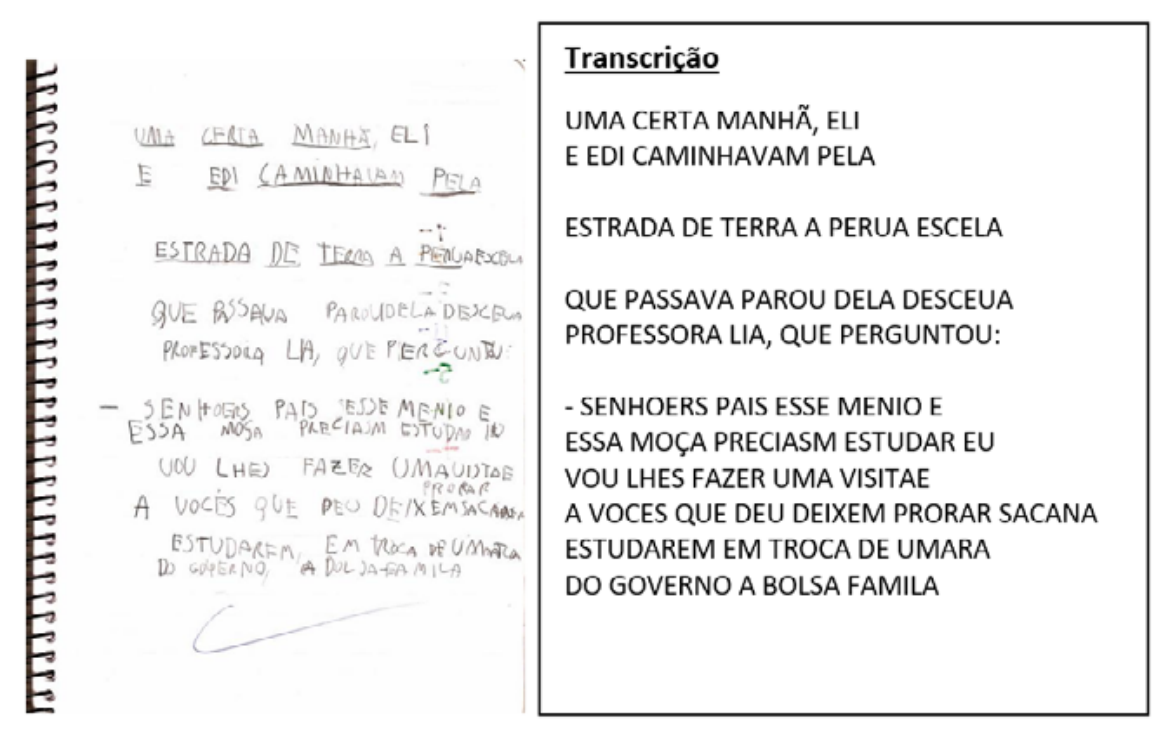

Fonte: Caderno escolar de RG

Observe-se que tanto na lista quanto no texto, mesmo sem a intervenção da professora, RG revela a relação entre fala e escrita e as hipóteses de quem está às voltas com a representação escrita de letras nas palavras. Na lista, na tentativa de escrever "gato", uma palavra com a qual deve estar mais familiarizado, escreve "GTOA". É possível perceber que RG sabe quais são as letras que compõem a palavra, porém não sabe como ordená-las adequadamente. Já no texto que parece ter sido copiado de algum outro lugar, constatamos que RG altera a ordem das letras de algumas sílabas complexas "SENHOERS" e "PRECIASM" - ou suprime letras para uma estrutura silábica mais comum no Português Brasileiro (CVCV) - como em "FAMILA". No entanto, ninguém lê o que RG escreve e nada é feito para que $R G$ avance nesse processo.

\section{Contradiscurso}

O que é possível constatar, a partir dos discursos da área médica, da prática clínica e escolar? É que a maneira como o corpo tem sido tomado como objeto de estudo, sobretudo pela área médica, tem produzido um excesso de patologização na infância, principalmente na criança em processo de escolarização (COUDRY, 2009, 2011; BORDIN, 2010; ANTONIO, 2011). E no caso de crianças com patologias de fato, tem impedido que elas aprendam efetivamente, uma vez que se parte do pressuposto de que são incapazes de aprender. 


\section{Metodologia}

A metodologia adotada é de natureza heurística e tem por fundamento o conceito de dadoachado, formulado por Coudry (1996, p. 183), "produto da articulação de teorias sobre o objeto que se investiga com a prática de avaliação e acompanhamento longitudinal de processos linguístico-cognitivos". Interpretar um fato como dado requer um método que nasce na prática, em ambiente discursivo e em ambiente experimental, e que supõe dois tempos: o da ocorrência do fato na interlocução e o da análise do fato transformando-o em dado. O intervalo de tempo entre a constatação do que é um fato e sua transformação em dado pode ser maior ou menor, quase-simultâneo ou não. Esse tipo de dado é sempre revelador e encobridor de fenômenos linguísticos e sua análise proporciona o movimento teórico, permitindo a resolução de alguns problemas e a colocação de outros (COUDRY, 1996).

Os pressupostos teóricos seguidos se alicerçam na Neurolinguística Discursiva (que será referida doravante como ND) ${ }^{5}$, que se fundamenta na variação funcional do cérebro determinada pela contextualização histórica dos processos linguístico-cognitivos (VYGOTSKY, 1997, 1998; LURIA, 1981), e se diferenciam radicalmente de uma visão de funcionamento cerebral médio e padrão para todos os falantes de uma língua natural. Nesse sentido, a ND se opõe à ideia de uma divisão estrita entre o que é da ordem do normal e do patológico, o que não significa que a patologia não exista: sempre que o aparelho cerebral for privado - por lesões congênitas e/ou adquiridas - de suas estruturas e funções, a patologia se estabelece (COUDRY; FREIRE, 2010). À ND interessa a relação heterogênea entre sujeito e linguagem e não uma relação preestabelecida entre a falta (para se atingir a normalidade) e a patologia; importam, assim, sujeitos comuns marcados por sua relação com a linguagem oral/escrita, práxis/corpo e percepção, e não sujeitos idealizados.

Na ND, são especialmente articulados a hipótese da historicidade e indeterminação da linguagem e os conceitos de trabalho e força criadora, formulados por Franchi (1992). Benveniste (1972) e Jakobson (1975) são autores-âncora em relação aos conceitos de (inter)subjetividade e dos níveis de funcionamento da linguagem. Luria (1981) e Freud (1891) são incorporados por sua aproximação no que diz respeito ao funcionamento dinâmico e integrado de cérebro/mente, em que a linguagem está representada em todo o cérebro e não localizada em suas partes/centros. Também destacam-se os conceitos de dispositivo de Foucault (1994) e contradispositivos de Agamben (2009).

5 Para saber mais sobre a teorização na área da Neurolinguística Discursiva, consultar o capítulo Pressupostos Teóricos-Clínicos da Neurolinguística Discursiva, de Coudry e Freire (2010), no livro Caminhos da Neurolinguística Discursiva: teorização e práticas com a linguagem. 
A ND incorpora a reflexão de Agamben (2009), a partir do conceito de dispositivo de Foucault (1994, p. 41), que o define como "qualquer coisa que tenha de algum modo a capacidade de capturar, orientar, determinar, interceptar, modelar, controlar e assegurar os gestos, as condutas, as opiniões e os discursos dos seres viventes". Assim, é possível entender que o excesso de patologização, inclusive no interior das patologias, como é o caso da SXF, funciona como um dispositivo que determina e captura o sujeito portador da SXF (processo de subjetivação), bem como orienta, controla e assegura as condutas, as opiniões e os discursos daqueles que fazem parte do entorno desse sujeito (familiares, educadores, fonoaudiólogos, entre outros). Como ensina Foucault, um dispositivo que condiciona saberes e práticas sobre a SXF.

Diante desse quadro, o que sobra do/ao sujeito? Como propõe Agamben (2009, p. 14):

[...] a estratégia que devemos adotar no nosso corpo-a-corpo com os dispositivos não pode ser simples, já que se trata de nada menos que liberar o que foi capturado e separado pelos dispositivos para restituí-lo a um possível uso comum. É nesta perspectiva que gostaria agora de falar-lhes de um conceito sobre o qual me ocorreu de trabalhar recentemente. Trata-se de um termo que provém da esfera do direito e da religião romana (direito e religião estão, não somente em Roma, estreitamente conectados): profanação. [...] A profanação é o contradispositivo que restitui ao uso comum aquilo que o sacrifício havia separado e dividido.

É preciso desenvolver práticas, portanto, que passem a funcionar como contradispositivos que atuem no corpo a corpo frente aos dispositivos que mantêm os sujeitos no lugar da não aprendizagem (COUDRY, 2009, 2011; BORDIN, 2010; ANTONIO, 2011). Para tanto, o sujeito deve ser visto para além da patologia, ou seja, um sujeito histórico, que vive em um determinado tempo, em uma determinada cultura, sem os quais não há possibilidade de linguagem.

\section{0 estudo desenvolvido}

Em estudo de caso, longitudinal, ao longo de três anos, foram acompanhados os portadores da SXF: PM (12 anos), AS (15 anos) e RG (19 anos) em sessões semanais individuais, com uma hora de duração (SILVA, 2014). PM e AS também eram acompanhados em sessões semanais em grupo no Laboratório de Neurolinguística (LABONE/IEL/UNICAMP). Ambos faziam parte do Centro de Convivência de Linguagens (CCazinho).

Apresento, a seguir, dados de um dos sujeitos acompanhados longitudinalmente (RG), de forma a contrapor o que foi observado nos dados com o discurso determinístico da área médica. 


\section{Relação sujeito da/na linguagem: na leitura e escrita de palavras}

Sabendo que RG é torcedor da Ponte Preta e gosta muito de futebol, em sessão individual, do dia 29 de abril de 2011, lemos notícias sobre o time, sua colocação no campeonato paulista e um pouco de sua história. Após a leitura, propus para RG (18 anos) construirmos nossos times de futebol de botão. Expliquei como era o jogo e lemos algumas regras. Decidimos fazer um time de botão titular e outro reserva com os jogadores da Ponte Preta. Pegamos os nomes de todos os jogadores na internet, lemos qual o papel de cada posição no time (goleiro, lateral, volante, atacante) e fizemos nossa escalação. Para tanto, a pesquisadora lia o nome de todos os volantes do time, por exemplo, e RG escolhia um ou dois deles para compor o seu time (a depender da posição) e os anotava em um papel. O dado abaixo mostra como ficou a escalação de RG.

Figura 4. Jogo de botão
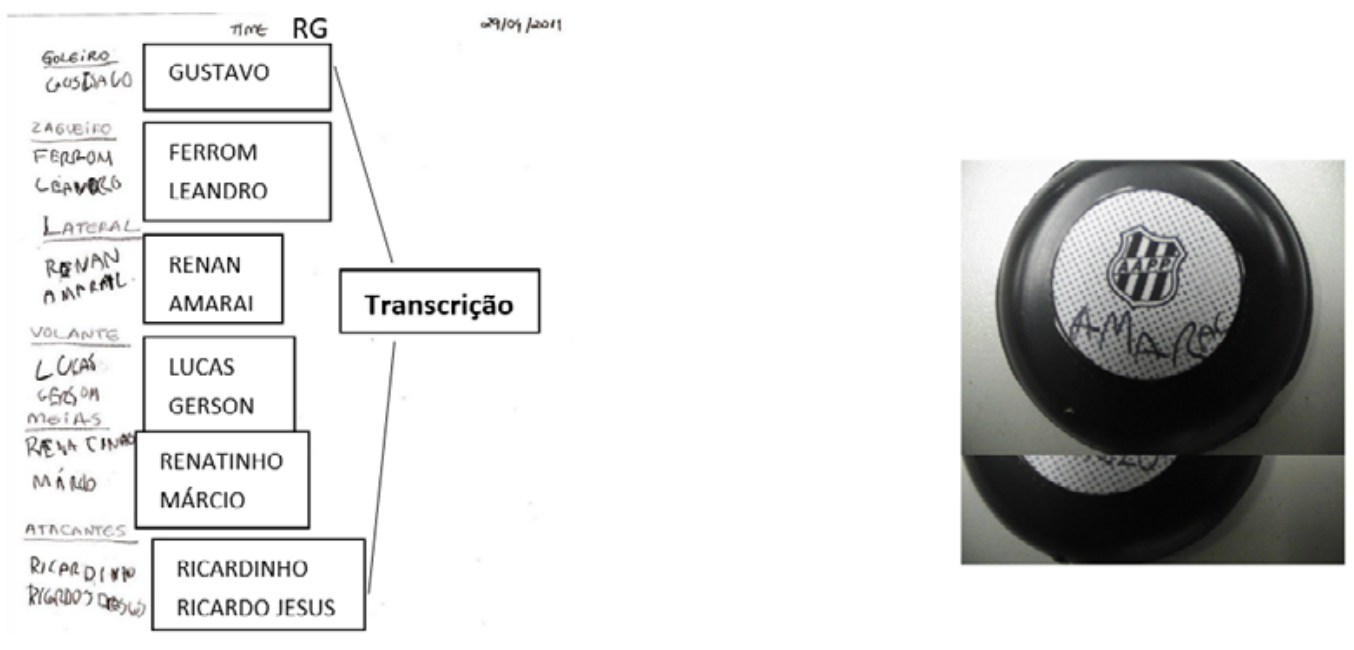

Fonte: BDN - CNPq n³07227/2009-0

Nesse dado de escrita, RG revelou saber os nomes das letras e suas formas gráficas. Não apresentou dificuldade em copiar e retomar os nomes dos jogadores depois que a pesquisadora os falava. Sua escrita, no entanto, é imprecisa, os traçados não são muito claros - apesar disso é possível entender o que RG escreve. Tal imprecisão está relacionada a gestos motores demandados pela escrita, ainda não automatizados, para desenhar os traçados das letras e ao fato de não ter muita experiência em escrever até então. Segundo Freud (1891), essa dificuldade atrapalha na articulação da imagem acústica/ sonora e visual com a motora, uma vez que essa relação ainda não foi automatizada.

RG altera a ordem das letras de alguns nomes - tem dificuldade em relação à ordem das letras e suas combinações, o que afeta a composição da palavra escrita. Entretanto, RG escreve e, com a intervenção da pesquisadora que retoma, sinaliza e dá sentido ao que RG escreve, ele também (re)escreve. Observem-se as refacções, que revelam a atividade 
epilinguística de RG: as hipóteses que vai formulando sobre a escrita de palavras e a estrutura de seus constituintes (ABAURRE, 2001).

Após a escalação, reescrevemos os nomes dos jogadores nos botões e observamos que a reescrita se torna mais precisa. Isso acontece porque ao tentar ler sua própria escrita da escalação dos jogadores, RG teve dificuldades para entender o que ele havia escrito. A leitura do que havia escrito possibilitou que RG percebesse que, para ser entendido, ele precisaria caprichar mais no traçado das letras. Por isso, na reescrita, se esforçou para deixar os traçados mais nítidos.

É esse trabalho com, sobre e na linguagem que possibilita que RG entre para o mundo das letras gradativamente. É nessa interação - que atua na zona de desenvolvimento iminente (VYGOTSKY, 1998) - que RG tem a possibilidade de construir e fortalecer as relações que ainda não estão estabelecidas entre aspectos acústicos/sonoros, motores/ cinestésicos e visuais que compõem a palavra a ser escrita. Isso, por sua vez, abre caminhos para que o sujeito compreenda suas dificuldades e avance no aprendizado da escrita, sendo que (re)escrever e ler com sentido é uma possibilidade para que isso aconteça.

\section{Relação sujeito da/na linguagem: na leitura e escrita de textos}

Em sessão do dia 10 de dezembro de 2011, lemos um livro chamado Meu pequeno brasileiro de Eduardo Bueno. Trata-se de uma história sobre um menino, chamado Dudu, que adorava futebol, mas não gostava das aulas de História porque as achava muito cansativas, cheias de datas e nomes compridos. Dudu fica triste porque tem que ir para a escola e vai perder a abertura da Copa do Mundo. Quando chega na escola, há um professor de História substituto que revoluciona a sala de aula com uma velha bola e um novo jeito de ensinar - Dudu passa a adorar a matéria.

Após termos lido o livro, sugeri ao RG (19 anos) que escrevêssemos uma carta para o Dudu contando como era a escola dele e para qual time ele torcia. A carta ficou assim: 
Figura 5. Carta

\begin{tabular}{|c|c|}
\hline 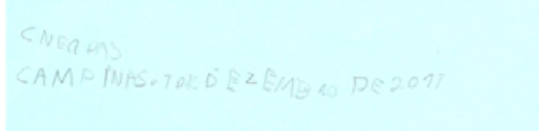 & $\begin{array}{l}\frac{\text { Transcrição }}{\text { CNERPAS }} \\
\text { CAMPINAS. } 1 \text { DE DEZEMBRO DE } 2011\end{array}$ \\
\hline 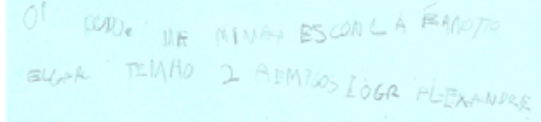 & $\begin{array}{l}\text { OI DUDU. NA MINHA ESCONLA É MUITO } \\
\text { ELGAR TEMHO } 2 \text { AEMIGOS IOGR ALEXANDRE }\end{array}$ \\
\hline 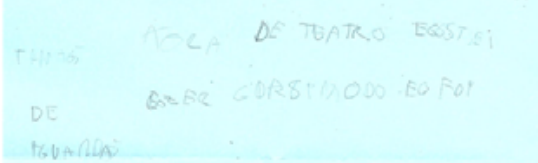 & $\begin{array}{l}\text { TENHO AOLA DE TEATRO EGOSTEI } \\
\text { DE EAZER CORSIMODO EO FOI } \\
\text { IGUARDA }\end{array}$ \\
\hline 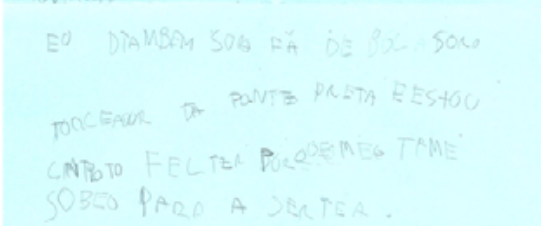 & $\begin{array}{l}\text { EU DTAMBEM SOA FÃ DE BOLA SORO } \\
\text { TORCEADOR DA PONTE PRETA EESTOU } \\
\text { CNTIOTO FELIZR PORQUE MEO TIME } \\
\text { SOBEO PARA A SERIEA. }\end{array}$ \\
\hline
\end{tabular}

Fonte: BDN - CNPq n³07227/2009-0

Neste dado, é possível constatar como as sílabas não canônicas se apresentam como barreiras nesse processo de aquisição e uso da escrita para RG: logr (Igor), corsimodo (Quasímodo), iguarda (guarda), elgar (legal), torceador (torcedor), cntioto (muito). RG está tentando descobrir quantas letras ele pode incluir nas sílabas e em que ordem elas devem ser escritas. Ele tem dificuldade em manejar a concomitância entre o acústico, o motor e o visual, o que faz com que apresente instabilidades, episódios intermediários de escrita (ABAURRE; COUDRY, 2008). Às vezes, preenche com letras os espaços como uma escrita preenchedora, que depois, com a intervenção da pesquisadora e de outros que interagem com RG, passa a ter função para ele. Nota-se que RG sabe que entre uma palavra e outra há um espaço, ele sabe organizar o texto; porém, como ainda não domina certas convenções, certas características do sistema alfabético, em alguns momentos segmenta menos e escreve "egostei", "eestou", "serieA" - como tantas outras crianças iniciantes de escrita fazem

Muitos pesquisadores (ABAURRE, 1999; CAGLIARI, 2004) têm relacionado a segmentação não convencional de palavras por crianças e jovens em processo de aquisição da leitura e da escrita a fatos de natureza fonético-fonológica. Casos de hipossegmentanção e hipersegmentação são analisados como indícios de padrões rítmico-entonacionais típicos da oralidade e parecem obedecer a princípios subjacentes ao estabelecimento de constituintes prosódicos (MULLER, 2013). RG, portanto, está fazendo hipóteses sobre a escrita, relacionando o que para ele é conhecido pela fala com aquilo que ainda não domina na escrita - o que mostra que ele está fazendo associações e refletindo sobre aquilo que escreve.

6 Veja dado 4 de LF, à época com 12 anos e cursando a sexta série, apresentado por Muller (2013), que escreve todumundo para "todo mundo". 
RG também usa letras parecidas acústica e visualmente no lugar de outras como em "temnho", "dtambem" - o que, da mesma forma, fazem os iniciantes de escrita. Esses dados mostram que RG sabe as similaridades acústicas e visuais que existem entre algumas letras. Um fato interessante que aparece na sua escrita é a substituição do " $u$ " pelo "o". RG escreve "aola", "eo", "meo", "sobeo". Muito provavelmente isso acontece, assim como com tantas outras crianças, porque alguém deve ter dito a RG que quando falamos "u", escrevemos "o" e isso ficou automatizado na escrita dele. Esse fato mostra como é equivocada a visão de linguagem que a escola e a clínica muitas vezes têm, por não compreenderem a íntima relação que a fala tem com a escrita, sobretudo para escreventes iniciais. Em nossa língua, é comum falarmos em muitas regiões, principalmente em final de palavra, "u" no lugar de "o": carru, amigu, meninu, cachorru. Entretanto, não é sempre que falamos "u" no lugar de "o": uva, continua, abuso, dúvida. No entanto, ninguém explicou para $R G$ essas diferenças.

Todas as instabilidades presentes no texto de RG, contudo, indicam que está fazendo um trabalho linguístico cognitivo - com, na e sobre a linguagem - que é extremamente relevante para que ele avance no processo de aquisição da leitura e escrita. RG nunca havia escrito uma carta antes e colocá-lo em contato com um gênero novo para ele possibilita que novos caminhos cognitivos sejam trilhados. É assim que RG vem tecendo hipóteses sobre a escrita e vem aprendendo a compor o sistema de representação alfabética, bem como suas possibilidades combinatórias para formar palavras.

\section{Relação sujeito da/na linguagem: na fala}

Em sessão individual, do dia 29 de setembro de 2011, a pesquisadora Ims propõe a RG (19 anos) o seguinte jogo: a partir de algumas imagens projetadas na tela de um computador, um jogador deve dar dicas ao outro jogador sobre o que é aquela imagem para que o segundo jogador tente adivinhar do que se trata. Antes de iniciarem, Ims dá um exemplo, depois RG dá dicas para Ims identificar o objeto visto por ele na tela do computador.

\begin{tabular}{|l|l|l|l|l|}
\hline $\begin{array}{c}\text { Código } \\
\text { de } \\
\text { Busca }\end{array}$ & $\begin{array}{l}\text { Sigla do } \\
\text { Locutor }\end{array}$ & \multicolumn{1}{|c|}{ Transcrição } & E. verbais & Enunciados não verbais \\
\hline & $R G$ & RECORTE & & \\
\hline & & & $\begin{array}{l}\text { Olha uma imagem na tela do } \\
\text { computador para dar dicas a } \\
\text { Ims }\end{array}$ \\
\hline$! ?$ & Ims & E aí, RG, qual é a dica? & & \\
\hline & $R G$ & É redonda & & \\
\hline & Ims & É redonda? & & \\
\hline & $R G$ & Preto e branco & & \\
\hline
\end{tabular}




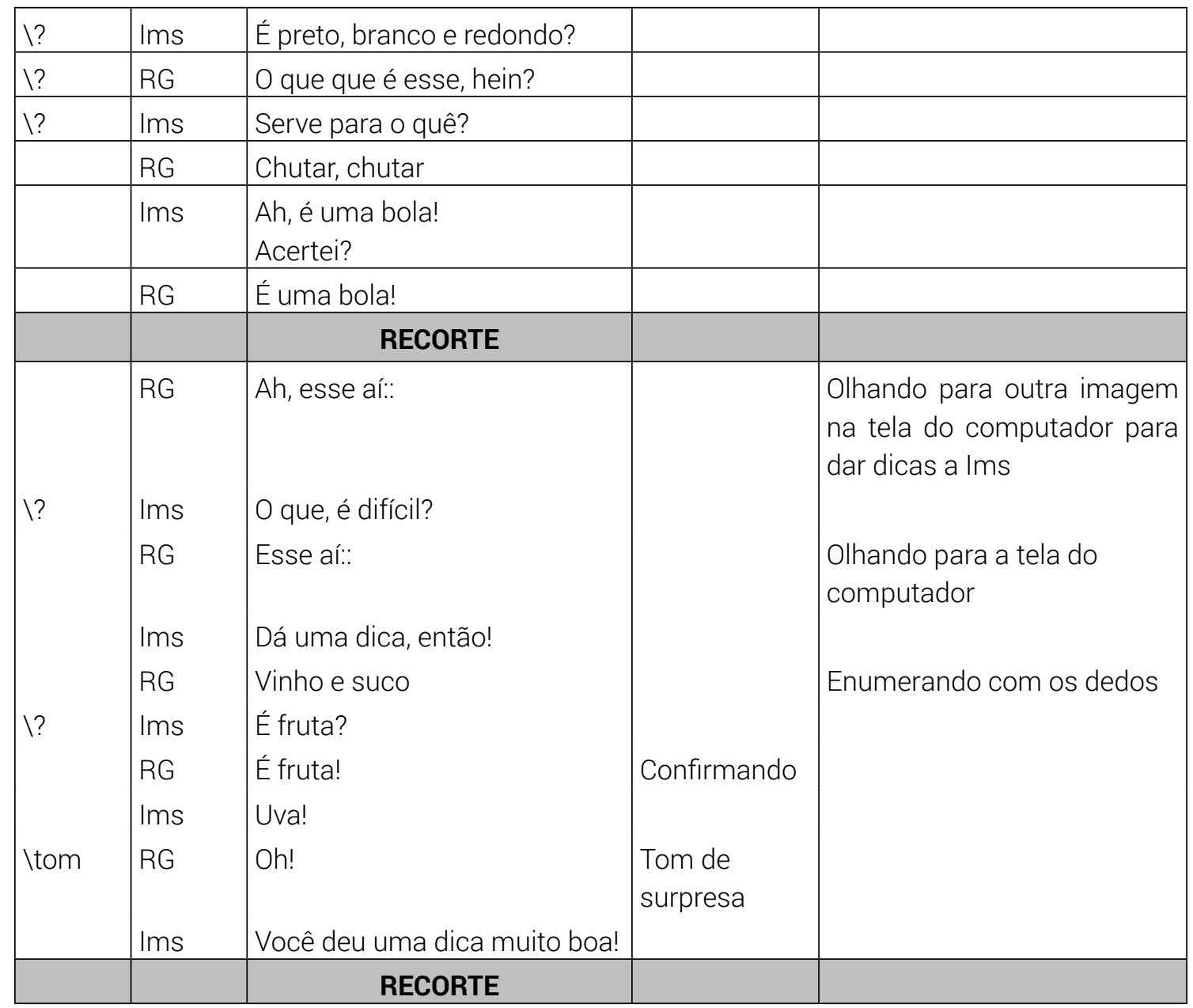

Fonte: BDN - CNPq n³07227/2009-0

Antes dos recortes apresentados, RG parece não saber exatamente como fazer o que foi proposto e Ims procura ajudá-lo fazendo perguntas que o direcionem. No entanto, para as duas imagens seguintes, RG dá as dicas sem que Ims tenha que fazer muitas perguntas, o que mostra que RG passa a compreender as regras do jogo à medida que escuta a pesquisadora, fala e joga. Isso porque, como afirma Vygostky (2007), a fala organiza o pensamento e ajuda nos processos de compreensão. O que é possível verificar nesse dado é que tanto a fala da pesquisadora, que inicialmente direciona $R G$, quanto a fala interna de RG, que o ajuda a refletir sobre a atividade, contribuem para a compreensão do jogo e o fazem ir além.

No primeiro recorte do dado, constatamos que RG não se restringe ao campo descritivo, como fez antes, mas observa a imagem e descreve para Ims aquilo que vê. A partir das perguntas que a pesquisadora faz, entra no jogo simbólico e passa a dar dicas relevantes ao investigador. Percebemos uma mudança significativa nas relações que RG estabelece 
com as coisas e com o outro pela linguagem, principalmente, no último recorte quando diz "vinho e suco" para referenciar "uva". A partir do momento em que RG compreende as regras do jogo, consegue realizar associações indiretas, inferências, refinando suas dicas.

Para que possamos entender melhor a complexidade do trabalho linguístico-cognitivo desenvolvido por RG, retomo, ainda que de maneira sucinta, os trabalhos de Luria (1981) sobre a estrutura psicológica da fala. O autor explica que o aspecto acústico (fásico) é apenas o primeiro componente na organização da função executiva do processo de fala:

O componente seguinte é a organização léxico-semântica do ato de falar, o que exige domínio do código léxico-morfológico da linguagem para possibilitar a conversão de imagens ou conceitos em seus equivalentes verbais [...]. A formação de uma tal rede de grupos morfológicos (felicidade, maldade ou ansiedade; solidão, devassidão ou ingratidão, e assim por diante) ou semânticos (hospital, escola, delegacia, de acordo com o princípio de "instituições públicas", ou diretor, enfermeira-chefe, inspetor, de acordo com o princípio de pessoa que dirige um estabelecimento) são exemplos especiais das categorias semânticas altamente complexas em que cada palavra que constitui a unidade generalizada da fala é incluída. (LUIRIA, 1981, p. 270-271).

É importante considerar que tais categorias são formadas a partir das vivências e usos que o sujeito fez e faz da linguagem durante sua vida. No caso de RG, podemos perceber que se, por um lado, não há um domínio da ordem sintática que estrutura a língua, por pouco uso significativo (não fala com ninguém e ninguém fala com ele), o que dificulta sua entrada no mundo das letras; por outro lado, as categorias semânticas possibilitam que produza enunciados com significado e fortaleça as relações que ainda não estão estabelecidas. Entrando no funcionamento discursivo da linguagem, que supõe a articulação dos níveis de análise linguística em função do sentido (BENVENISTE, 1972), aprendendo e vivenciando regras de uso, socialmente estabelecidas, o que se apresentava como barreiras para aprender deixa de funcionar e novos caminhos se abrem frente à linguagem (no caso a entrada na leitura e na escrita que demandam estruturas próprias, novas para ele).

Considerando as contribuições de Vygotsky (1997) a respeito dos dois planos da linguagem: aspecto físico, sonoro - exterior e aspecto semântico - interior, podemos ainda dizer que RG permanece muito mais atrelado ao aspecto semântico da linguagem, ao passo que hesita no aspecto físico, sonoro e na relação entre esses dois planos.

Para estabelecer tais relações, $R G$ realiza um trabalho linguístico-cognitivo extremamente complexo: para dar as dicas a Ims, RG tem que reconhecer a imagem, saber o significado do objeto que está vendo, relacioná-lo a uma rede de palavras e escolher, dessa rede, quais palavras ele pode usar para referenciar este objeto, sem dizer o seu nome. 
Portanto, RG deve buscar, a partir das relações que estabeleceu ao logo de sua vivência e experiência com a linguagem, palavras que se relacionam a este objeto - o que envolve relacionar o objeto e seu nome a toda uma rede semântica (matriz semântica) de combinações possíveis e selecionar dessa rede as palavras necessárias no contexto do jogo. É pela via do sentido (FREUD, 1891) que RG vai, aos poucos, entrando para o mundo das letras.

\section{Considerações finais}

Os dados e análises mostram que RG foi resgatado como sujeito da linguagem: na relação com o outro, na linguagem e no discurso está transpondo barreiras que foram estabelecidas para o sujeito portador da SXF, tornando-o incapaz de aprender a ler e escrever e impedindo qualquer mudança/avanço - como é postulado em muitos trabalhos e práticas clínicas, por profissionais da área médica.

Nesse contexto, destaco o papel e a responsabilidade do linguista, como especialista e estudioso da linguagem, que deve ocupar seu lugar e se contrapor ao discurso da área médica. Discurso esse que não é especializado sobre os estudos da linguagem, mas, ainda assim, parte do seu campo de saber sobre a doença para determinar as (im) possibilidades do sujeito sobre a linguagem.

A ND discute essas questões e traz alternativas de trabalho com a linguagem que possibilitam que os sujeitos avancem em seu processo de aquisição e uso da leitura e escrita - tão primordial para que as funções cerebrais complexas se inter-relacionem e se desenvolvam. Isso porque a premissa é investir no sujeito, independentemente de seu diagnóstico/prognóstico.

Não queremos, com isso, negar a doença. Se existe uma questão orgânica que afeta o funcionamento cerebral, como é o caso da SXF, é possível que haja processos interrompidos/barrados/alterados. O que levantamos como questão é que há uma banalização que acompanha o diagnóstico que muito nos preocupa, uma vez que legitima alguns prognósticos e práticas que mantêm o sujeito no lugar da não aprendizagem. Somos capturados pelos dispositivos aí instituídos de tal forma que ficamos presos a um círculo vicioso sem saída: a doença explica qualquer comportamento e dificuldade que o sujeito apresenta e essas dificuldades não são consideradas passíveis de mudança em função da doença - por isso, as práticas ficam limitadas, uma vez que determinadas atividades não são realizadas com o sujeito porque parte-se do pressuposto que esse sujeito será incapaz de realizá-las, impossibilitando seu avanço/desenvolvimento.

Retomo os estudos de Agamben (2009) sobre a contemporaneidade e a profanação. Nas frestas do presente, temos que encontrar saídas para enfrentar os dispositivos e 
trazer ao uso comum aquilo que foi dignificado nos discursos hegemônicos da medicina como se fossem verdades absolutas, eternas e inquestionáveis. Como postula a ND, só assim construiremos e trilharemos caminhos alternativos para alfabetizar e promover o desenvolvimento - entendido aqui como modificação do sujeito a partir da relação com o outro e o mundo - de sujeitos outrora condenados a permanecer no lugar da não aprendizagem.

Assim, finalizo, ressaltando a relevância de estudos longitudinais que buscam enxergar possibilidades para além dos déficits e transtornos estabelecidos de antemão, para que as condutas terapêuticas e escolares não mantenham esses sujeitos no lugar do não sentido, no lugar da impossibilidade de aprender.

Destaco, aqui, mais uma vez o papel e a responsabilidade do linguista que traz continuidade ao processo de aquisição e uso da fala/leitura/escrita no lugar das constantes rupturas - uma luz no fim do túnel.

\section{REFERÊNCIAS}

ABAURRE, M. B. M. Dados da escrita inicial: indícios de construção da hierarquia de constituintes silábicos? In: HERNANDORENA, C. L. M. (org.). Aquisição de Língua Materna e de Língua Estrangeira: aspectos fonético-fonológicos. Pelotas: EDUCAT/ALAB, 2001. p. 63-85.

ABAURRE, M. B. M. Apontamentos sobre aquisição da escrita: refacção e reescrita de textos. Ciências e Letras, Porto Alegre, v. 26, p. 97-132, 1999.

ABAURRE, M. B. M.; COUDRY, M. I. H. (1987). A relação entre trocas linguísticas de sujeitos afásicos e de crianças no processo de aquisição da língua escrita. Estudos da Lingua(gem), Vitória da Conquista, v. 6, n. 2, p. 173-193, 2008.

AGAMBEN, G. O que é o contemporâneo? E outros ensaios. Tradução Vinícius N. Honesko. Chapecó: Argos, 2009.

ANTONIO, G. D. R. Da sombra à luz: a patologização de crianças sem patologia. 2011. Dissertação (Mestrado em Linguística) - Instituto de Estudos da Linguagem, Universidade Estadual de Campinas, Campinas, 2011.

BENVENISTE, E. Problemas de Linguística Geral I. Tradução Maria da Gloria Novak e Luiza Neri. São Paulo: Cia. Ed. Nacional e Ed. da USP, 1972. 
BORDIN, S. M. S. Fala, leitura e escrita: encontro entre sujeitos. 2010. Tese (Doutorado em Linguística) - Instituto de Estudos da Linguagem, Universidade Estadual de Campinas, Campinas, 2010.

BOY, R.; CORREIA, P. S.; LLERENA, J. C.; MACHADO-FERREIRA, M. C.; PIMENTEL, M. M. G. Síndrome do $x$ frágil: estudo caso-controle envolvendo pacientes pré e pós-puberais com diagnóstico confirmado por análise molecular. Arquivos de Neuropsiquiatria, v. 59, n. 1, p. 83-88, 2001.

CAGLIARI, L. C. Alfabetização \& Linguística. 10. ed. São Paulo: Scipione, 2004.

COUDRY, M. I. H. Caminhos da Neurolinguística Discursiva: teorização e práticas com a linguagem. Campinas: Mercado de Letras, 2010.

COUDRY, M. I. H. Despatologizar é preciso: a experiência do CCazinho. Anais do II Simpósio Mundial de Estudos de Língua Portuguesa, Évora, p. 97-117, 2009.

COUDRY, M. I. H. O que é dado em Neurolinguística? In: CASTRO, M. F. C. P. de (org.). 0 método e o dado no estudo da linguagem. Campinas: Editora da UNICAMP, 1996. p. 179-194.

COUDRY, M. I. H. Diário de Narciso: discurso e afasia. 1986. Tese (Doutorado em Linguística) - Instituto de Estudos da Linguagem, Universidade Estadual de Campinas, Campinas, 1986.

COUDRY, M. I. H.; FREIRE, F. M. P. Neurolinguística discursiva: teorização e prática clínica. Pressupostos teórico-clínicos da Neurolinguística Discursiva. Campinas: Mercado de Letras, 2010.

DARNEL, J. C.; JENSEN, K. B.; JIN, P.; BROWN, V.; WARREN, S. T.; DARNEL, R. B. Fragile $X$ mental retardation protein $\mathrm{mRNA}$ targets harboring intramolecular G-quartets encode proteins related to synaptic function. Cell, v. 107, p. 489-499, 2001.

FERREIRA, G. C.; LAMÔNICA, D. A. C. Caracterização da linguagem na síndrome do x-frágil: estudo bibliográfico. Pró-Fono Revista de Atualização Científica, v. 17, n. 1, jan.-abr. 2005.

FOUCAULT, M. Os anormais: curso no Collège de France (1974-1975). Tradução E. Brandão. São Paulo: Martins Fontes, 2001. 
FOUCAULT, M. Le jeu de Michel Foucault. Dits et écrits III. Paris: Éditions Gallimard, 1994. p. $298-329$.

FRANCHI, C. Linguagem - Atividade Constitutiva. Cadernos de Estudos Linguísticos, v. 22, p. 9-39, 1992 [1977].

FREUD, S. A interpretação das afasias. Tradução Ramón Alcalde. Buenos Aires: Ediciones Nueva Visión, 1891.

FUNDAÇÃO BRASILEIRA DA SÍNDROME DO X-FRÁGIL. Disponível em: www.xfrafil.com. br. Acesso em: 04 set. 2010.

GUERREIRO, M. M. Fragile x syndrome: clinical, electroencephalographic and neuroimaging characteristics. Arquivos de Neuropsiquiatria, v. 56, n. 1, p. 18-23, 1998.

HODAPP, R. M.; DYKENS, E. M.; HAGERMAN, R. J.; SCHREINER, R.; LACHIEWICZ, A. M.; LECKMAN, J. F. Developmental implications of changing trajectories of IQ in males with fragile X syndrome. J Am Acad Child Adolesc Psychiatry, v. 29, p. 214-219, 1990.

JAKOBSON, R. Dois aspectos da linguagem e dois tipos de afasia. Linguística e comunicação. São Paulo: Cultrix, 1975.

LURIA, A R. Fundamentos de Neuropsicologia. São Paulo: EdUSP, 1981.

MULLER, L. M. Crianças e jovens diagnosticados de Dislexia: o que seus dados de escrita revelam? 2013. Dissertação (Mestrado em Linguística) - Instituto de Estudos da Linguagem, Universidade Estadual de Campinas, Campinas, 2013.

SILVA, M. A. Sujeitos e Linguagem na Sinrome do X-Frágil. 2014. Tese (Doutorado em Linguística) - Instituto de Estudos da Linguagem, Universidade Estadual de Campinas, Campinas, 2014.

SPINELLI, M.; ROCHA, A. C.; GIACHETI, C. M.; RICHIERI-COSTA, A. Word-finding difficulties, verbal paraphasias, and verbal dyspraxia in tem individual with fragile $X$ syndrome. Am J Med Genet, v. 60, p. 39-43, 1995.

SUDHALTER, V.; MARANION, M.; BROOKS, P. Expressive semantic deficit in the productive language of males with fragile X Syndrome. Am J Med Genet, v. 43, p. 65-71, 1992. 
VYGOTSKY, L. S. A Formação Social da Mente. São Paulo: Martins Fontes, 1998.

(Tradução inglesa dos originais russos de 1934).

VYGOTSKY, L. S. Obras Escogidas. Tradução Julio Guillermo Blank. Madrid: Visor, 1997 (Tradução espanhola dos originais russos de 1924 a 1934).

YONAMINE, S. M.; SILVA, A. A. Características da comunicação em indivíduos com a Síndrome do X-Frágil. Arquivos de Neuropsiquiatria, v. 60, n. 4, p. 981-985, 2002. 